\title{
THE INFLUENCE OF FINISH TOOLING ON FRICTION PROPERTIES OF STEEL APPLIED TO SEA WATER PUMP SHAFTS
}

\author{
Wojciech Labuda, Adam Charchalis \\ Gdynia Maritime University \\ The Faculty of Marine Engineering \\ Morska Street 83, 81-225 Gdynia \\ tel.: +48586901549 , Fax: +48586901399 \\ e-mail:wlabuda@am.gdynia.pl,achar@am.gdynia.pl,
}

\begin{abstract}
Angular momentum pumps are very often applied on-board ships. These pumps are used in cooling circuits of medium and high power engines, power plant boilers as well as bilge, ballast and fire installations. Such an extensive use of angular momentum pumps on board is connected with their numerous advantages. However, during operation the wear of marine hull, the rotor and shaft seals take place. The research attempts to increase the service life of shafts.

The article presents the research results referring to the analysis of the influence of finish treatment (finishing turning, grinding, burnishing) on the friction properties of steel applied to marine pump shafts. The research was performed on a roller $39 \mathrm{~mm}$ in diameter made of $304 \mathrm{~L}$ stainless steel. The finish tooling of pump shaft pins was carry out on a universal centre lathe. The finish turning process was carried out by means of a WING WF 080408 Sandvik Coromant cutting tool with replaceable inserts. The grinding process was performed by grinding attachment for lathes. The 1-80x10x32-99C 80-N V grinding wheel was used for the process. The process of burnishing was done by SRMD single roll burnishing tool by Yamato. The burnishing process was carried out at the following technological parameters: burnishing force $1.1 \mathrm{kN}$, burnishing speed $35 \mathrm{~m} / \mathrm{min}$, feed $0.13 \mathrm{~mm} / \mathrm{rev}$. In addition, the influence of the number of burnishing tool passes on the friction was determined. The paper will present the research results of test on the friction properties examination of samples after finish machining. The experiment was performed on T-05 block-on-ring wear tester.
\end{abstract}

Keywords: plastic tooling, burnishing, stainless steel, angular momentum pump, friction properties

\section{Introduction}

One of the greatest problems of modern production techniques is the achievement of an appropriate quality at minimal costs and accompanied by the production efficiency increase. Therefore, while designing the production process, the technology used should have a considerable influence on the durability and reliability of machine parts to be produced. During finish treatment, the final dimensions as well as functional properties are imparted to a given element by application of proper treatment type. The process engineer has a range of production techniques to choose for the proper surface layer formation. It is crucial to find a suitable solution which will meet the requirements as well as the work conditions of a given machine part. The traditional finish treatment methods of marine pump shafts include grinding and finish turning. Industrial requirements make it necessary to reach the surface of high precision (3-5 accuracy class) simultaneously ensuring the roughness of $\mathrm{R}_{\mathrm{a}}=0.16-0.01 \mu \mathrm{m}$. Such an effect can be obtained by proper treatment methods of high accuracy.

A popular ability of a material to resist wear in given friction conditions is called resistance to tribologic wear. According to recent literature, the mechanism of the phenomena occurring during mechanical wear of surface layer and its relation with the finish treatment applied is mainly connected with the comparison of quantitative dependence between the wear in the comparable operating conditions of surfaces that underwent various ways of surface layer formation. The 
laboratory research on surface layer wear mechanisms applied in the field of machine construction is related to the exact application in industry, which has a direct correlation with the fact that the surface layer must have strictly defined values. Therefore, a wide knowledge of the dependence between microstructure, hardness and tribologic properties is required. From the point of view of tribology, the most important changes that the burnishing technology introduces into the surface layer are related with surface roughness and hardness. During the cooperation of a tribologic pair, the changes in surface structure and geometry occur when compared to the initial state. During the process of abrasive and corrosive wear in the technological surface layer, it is possible to observe the deformation processes of the roughness peaks, their abrasion and ridging which results in its permanent transformation. The surfaces without sharp peaks are characterized by better resistance to abrasion.

Vessels and warships are equipped with main propulsion engines, generating sets and auxiliary machinery, which are used in the engine room as well as on deck. Seawater pumps belong to a group of centrifugal angular momentum pumps. Their wide application on board vessels is related to their numerous advantages, which comprise simple construction, good performance characteristic, easy adjustment, quiet work and the possibility of applying direct electric motor drive. Centrifugal angular momentum pumps are utilized in the cooling system of high and medium speed engines, for supplying boilers, in bilge systems, ballast systems and in firefighting installations. During their service, the wear of pump body, rotor, sealing and shaft takes place. The research work was made an effort to improve the shafts service durability and was based on carrying out tests for contact fatigue, friction wear and electrochemical corrosion.

Due to hard service conditions, marine pumps working in seawater environment are made of corrosion resistant materials. In spite of the fact that pump shafts are made of an expensive material, it is not possible to avoid service damage. This damage includes cracking, plastic deformation, excessive wear of pins in places of mounting rotor discs and sealing chokes, corrosive wear, friction wear, erosive wear and splineways knock outs. During service experience, the most common problem that is observed is excessive wear of pins causing their diameter decrease as well as exceeding the permissible shape deviations in place of chokes mounting.

The technology used in production process has a vital influence on the reliability and service life of machine parts. The final formation of surface layer, that is the dimensions and service properties, is achieved during finish treatment of a given element. The basic methods of final tooling of shafts include precise lathing, grinding or burnishing operation.

The process of burnishing shafts proposed here aims at increasing the service durability of marine pump shafts of seawater installations, which should give economic benefits in comparison with traditional methods. Burnishing process enables the achievement of high smoothness of machined surface together with the surface layer hardening. This process has been performed in industrial experience on universal machine tools and on CNC machines but it is regarded as plastic tooling. Therefore, the final formation of dimensions and service properties with the use of burnishing constitutes a chipless and dustless treatment, which allows for ranking burnishing among ecological tooling methods.

Burnishing process enables surface working at high dimensional precision (accuracy class 7 and 6) which makes it possible to achieve such advantages as [10,11]:

- ability to reach high surface smoothness $\left(\mathrm{R}_{\mathrm{a}}=0.32-0.04 \mu \mathrm{m}\right)$

- increase of the surface hardness,

- increase of resistance to surface as well as volumetric fatigue,

- increase of resistance to abrasive and scuffing,

- lack of abrasive grain, chips, sharp and hard built-up edge fragments and on burnished surface,

- ability to use burnish tools on universal lathes ( the concept of one stand working ),

- elimination or reduction of the time consuming operations such as: honing, lapping, grinding and polishing, 
- ability to eliminate heat treatment in specific cases,

- high process efficiency (one pass of a tool) and reduction of production costs,

- high durability of burnishers,

- reduction of expenses related to machine parts production.

Many scientific centres all over the world deal with burnishing treatment. Research programs usually cover issues related to burnishing of cast iron, some heat resisting alloys, stainless steel, copper and aluminium alloys, titanium and its alloys, composite and intermetallic coatings [4, 5, 9] as well as parts produced by sintering metal powders.

The surface layer of material is specifically subjected to various degradable factors. However, it is not possible to avoid adverse phenomena of surface degradation during working conditions as well as corrosive influence of work environment. Therefore, the aim of the paper is to obtain proper technological quality and suitable service properties of angular momentum pump shaft pins applied to sea water systems in marine engines. Within the research, the optimization of burnishing technological parameters was carried out and the influence of the number of burnishing tool passes on the hardness and stereo metric parameters of angular momentum pump shaft pins was defined. Therefore burnishing should be performed on account of the minimization of $\mathrm{R}_{\mathrm{a}}$ surface roughness factor as well as maximization of $\mathrm{S}_{\mathrm{u}}$ surface layer relative hardness degree.

\section{Samples preparation}

The process of finish machining of shaft pins $\phi 39 \mathrm{~mm}$ in diameter (Fig. 1), made of X5CrNi18-10 stainless steel was carried out on a universal CDS 6250 BX-1000 centre lathe.
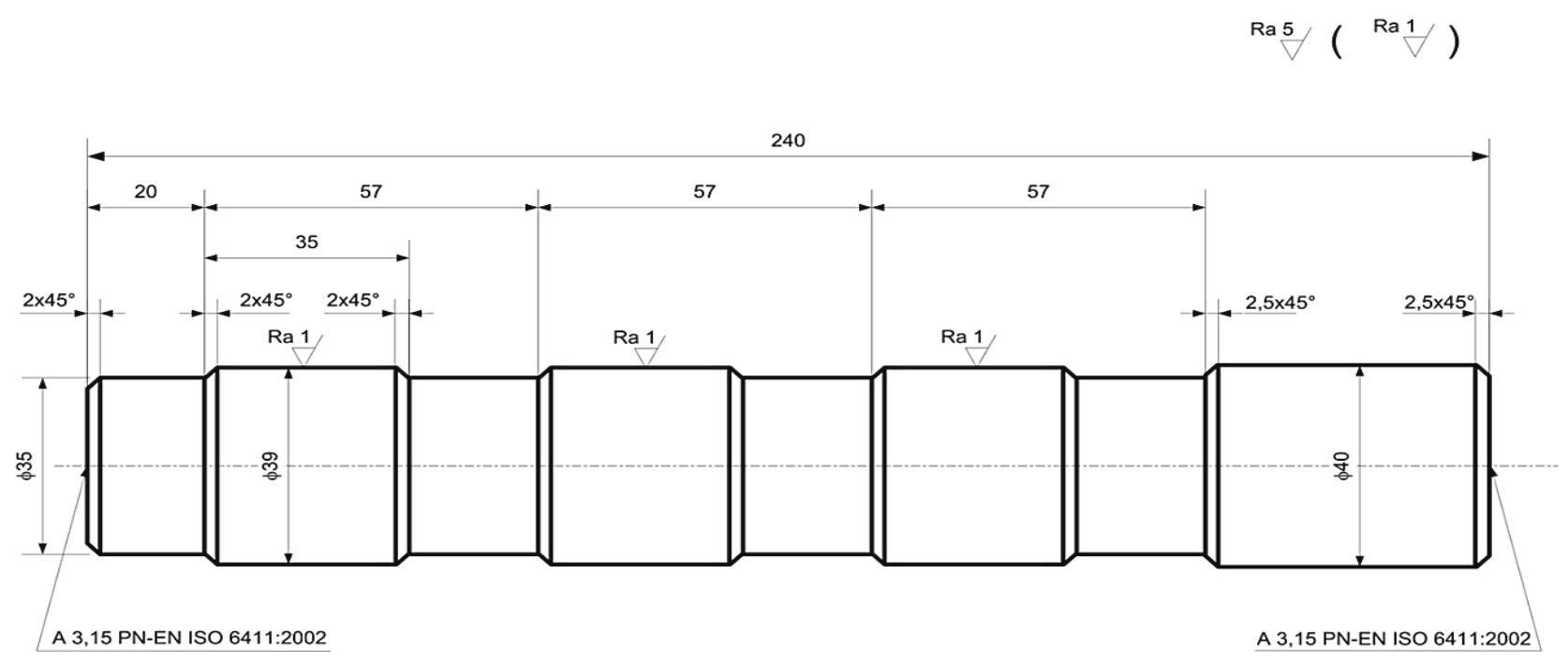

Fig. 1. Sample used in the resarch

The preliminary lathing process was conducted by a cutting tool with WNMG 080408 WF removable plates by Sandvik Coromant. The super finishing Wiper plates ensure high efficiency of finishing and semi - finishing treatment. Properly designed geometry made it possible to apply two times more feed at the same surface finishing quality in comparison with traditional plates. Therefore during the preliminary lathing (Fig. 2.a) the following machining parameters were used: machining speed $\mathrm{V}_{\mathrm{c}}=112 \mathrm{~m} / \mathrm{min}$, feed $\mathrm{f}=0.13 \mathrm{~mm} / \mathrm{rev}$, machining depth $\mathrm{a}_{\mathrm{p}}=0.5 \mathrm{~mm}$. The grinding process was performed by grinding attachment for lathes (Fig. 2.b). The $1-80 \times 10 \times 32-99 \mathrm{C} 80-\mathrm{N}$ $\mathrm{V}$ grinding wheel was used for the process.

The process of burnishing (Fig. 3a) was conducted by SRMD single roll burnishing tool by Yamato (Fig. 3b). Within the research, the optimization of burnishing technological parameters was conducted on account of the mineralization of $R_{a}$ surface roughness coefficient as well as the 
maximization of $S_{u}$ degree of surface layer relative hardness $[1-3,7,8]$. The applied parameters of technological process of surface tooling were presented in Tab. 1. The research also covered the determination of the influence of burnish tool passes number on friction properties.
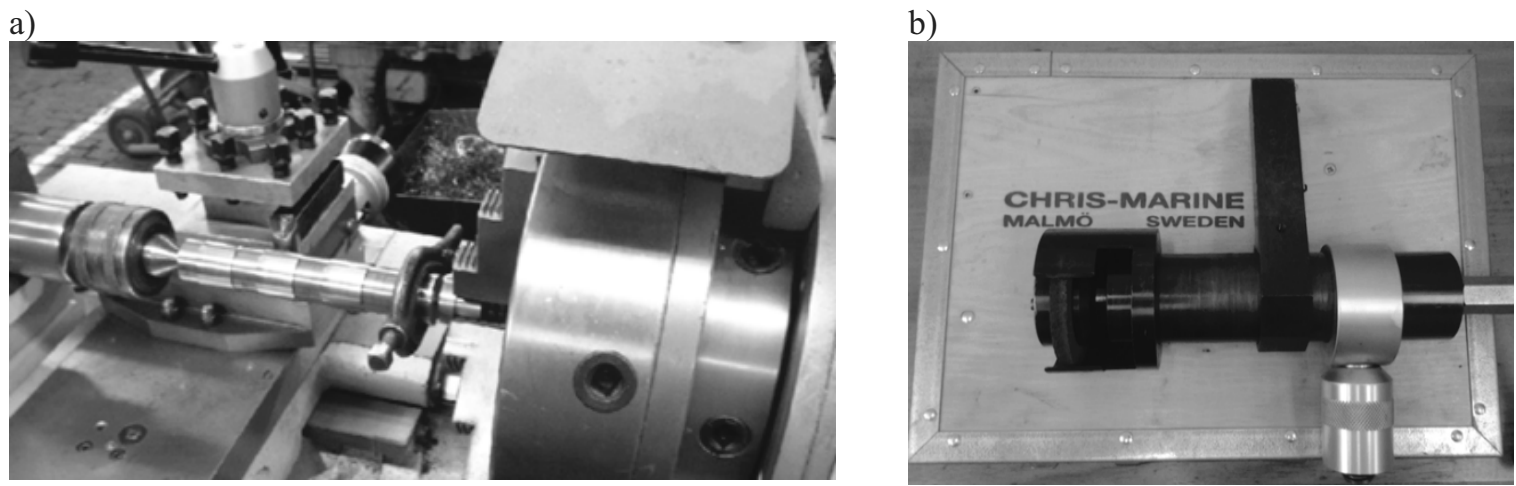

Fig. 2. a) The view of working assembly - lathing, b) Grinding attachment for lathes

a)

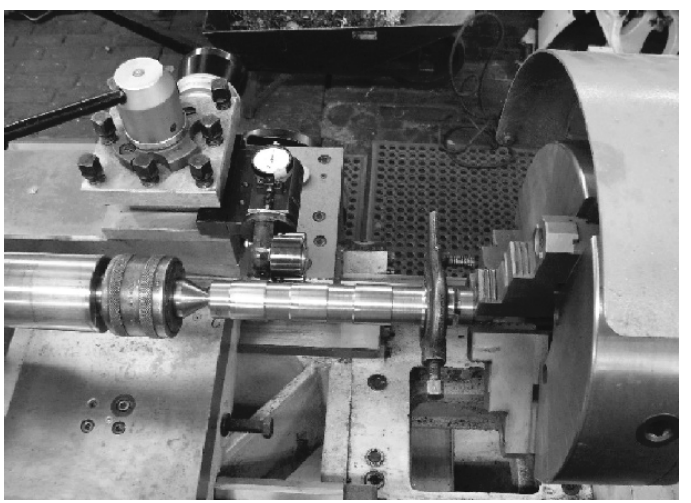

b)

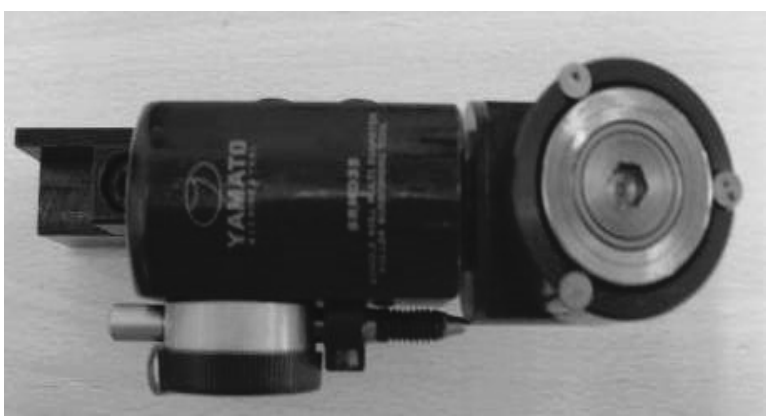

Fig. 3. a) The view of working assembly (machine tool, fixture, object, tool) - burnishing, b) Burnishing tool

Tab. 1. Technological parameters of burnishing process

\begin{tabular}{|c|c|c|}
\hline \multicolumn{2}{|c|}{ Parameter } & Values \\
\hline Burnishing force $-\mathrm{F}$ & {$[\mathrm{kN}]$} & 1.1 \\
\hline Burnishing speed $-\mathrm{V}_{\mathrm{n}}$ & {$[\mathrm{m} / \mathrm{min}]$} & 35 \\
\hline Feed $-\mathrm{f}$ & {$[\mathrm{mm} / \mathrm{rev}]$} & 0.08 \\
\hline
\end{tabular}

\section{Research methodology}

T-05 tester (Fig. 4) is designed to examine the tribologic properties of lubricating agents such as plastic grease, oil, solid oil. It can be used to test the resistance to material wear during metal and plastic friction and also to test the resistance to mashing layers applied to machine elements of great load. The tester allows carrying our examinations according to the requirements of the following standards: ASTM D 2714, ASTM D 2981, ASTM D 3704, ASTM G 77.

The tribologic characteristics were assigned for the cooperating elements manufactured by means of different finish treatment methods, used in the process of marine pump shafts production. The experiment consisted in pressing down the immovable counter sample (a block) with a given force $\mathrm{P}$ on a roll revolving in one direction at a given speed, which constituted a sample, made of stainless steel that underwent proper technological production process.

The examination of wear intensity was performed by measuring the mass decrement at $10 \mathrm{~min}$ intervals. The mass decrement was measured by an electronic weighing machine at an accuracy of $0.0001 \mathrm{~g}$. All parameters of the examined friction wear are presented in Tab. 2. 


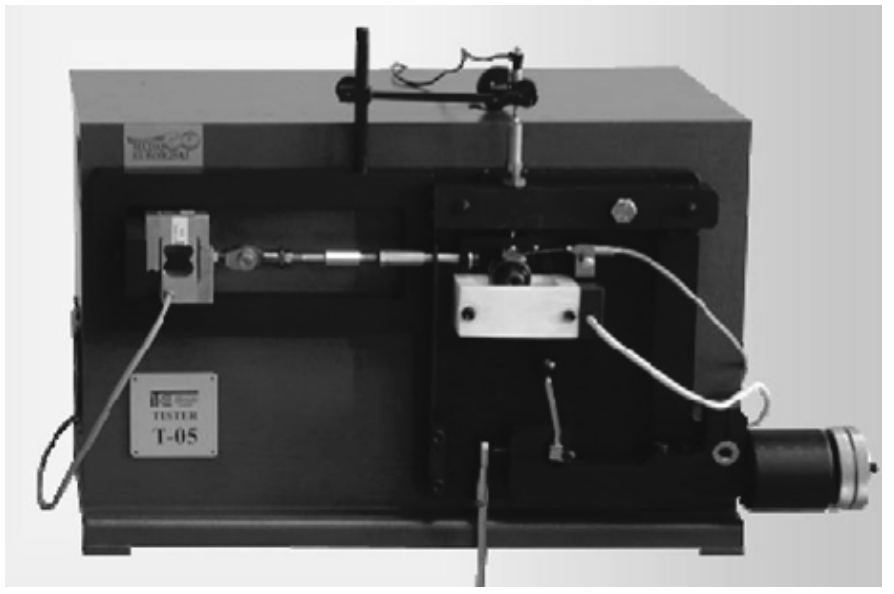

Fig. 4. T-05 Block - roll tester machine

Tab. 2. Research plan of wear intensity

\begin{tabular}{|c|c|c|c|c|c|c|}
\hline \multicolumn{7}{|c|}{ Wear intensity at $\mathrm{n}=600 \mathrm{rev} / \mathrm{min}$ and $\mathrm{P}=600 \mathrm{~N}$} \\
\hline Time $[\mathrm{min}]$ & 10 & 20 & 30 & 40 & 50 & 60 \\
\hline
\end{tabular}

The tests defining the influence of load changes on friction factor change were conducted on T05 machine at constant rotating speed. All parameters of the examined friction wear are presented in Tab. 3. The tests defining the influence of rotational speed changes on friction factor change were conducted on T05 machine at constant load. All parameters of the examined friction wear are presented in Tab. 4. The counter sample was made of C45 material. The tribological couple was lubricated by machine oil enriched with a MotorLife additive.

Tab. 3. Research plan of friction factor

\begin{tabular}{|c|c|c|c|c|c|c|}
\hline \multicolumn{7}{|c|}{ The effect of load change at constant rotational speed $\mathrm{n}=600 \mathrm{rev} / \mathrm{min}$} \\
\hline Force $[\mathrm{N}]$ & 100 & 200 & 300 & 400 & 500 & 600 \\
\hline
\end{tabular}

Tab. 4. Research plan of friction factor

\begin{tabular}{|l|c|c|c|c|c|c|c|}
\hline The effect rotational speed of change at constant load $\mathrm{P}=600 \mathrm{~N}$ \\
\hline Rotational speed [rev/min] & 100 & 200 & 300 & 400 & 500 & 600 & 700 \\
\hline
\end{tabular}

\section{Research results}

The friction wear measurements that were conducted proved that the highest mass decrement occurred in case of ground shaft pins $(\Delta \mathrm{m}=114 \mathrm{mg}$ - at testing pass time $=60 \mathrm{~min})$. The lowest wear was observed in case of shafts that were burnished three times. After 60 minutes of tribometer work, the $81 \mathrm{mg}$ of mass decrement was noted.

Tribological examinations (Fig. 5) showed that during the first 10 minutes of testing pass time the turned shaft pins suffered the most intensive wear $(I=122 \mathrm{mg} / \mathrm{h})$. The lowest wear intensity was observed for the shafts that were burnished 3 times ( $=79 \mathrm{mg} / \mathrm{h}$ ). It should be noted, however, that the wear intensity values for turned shafts was decreasing with time and reached the value of $\mathrm{I}=90 \mathrm{mg} / \mathrm{h}$. In addition, the wear intensity of ground shaft pins was increasing during the examination process time from $103 \mathrm{mg} / \mathrm{h}$ to $114 \mathrm{mg} / \mathrm{h}$. In case of shafts that were burnished once or three times the wear intensity was actually not changing. We can conclude; therefore, that in case of burnished shafts the effect of lapping does not occur on plastically treated pins surfaces. 


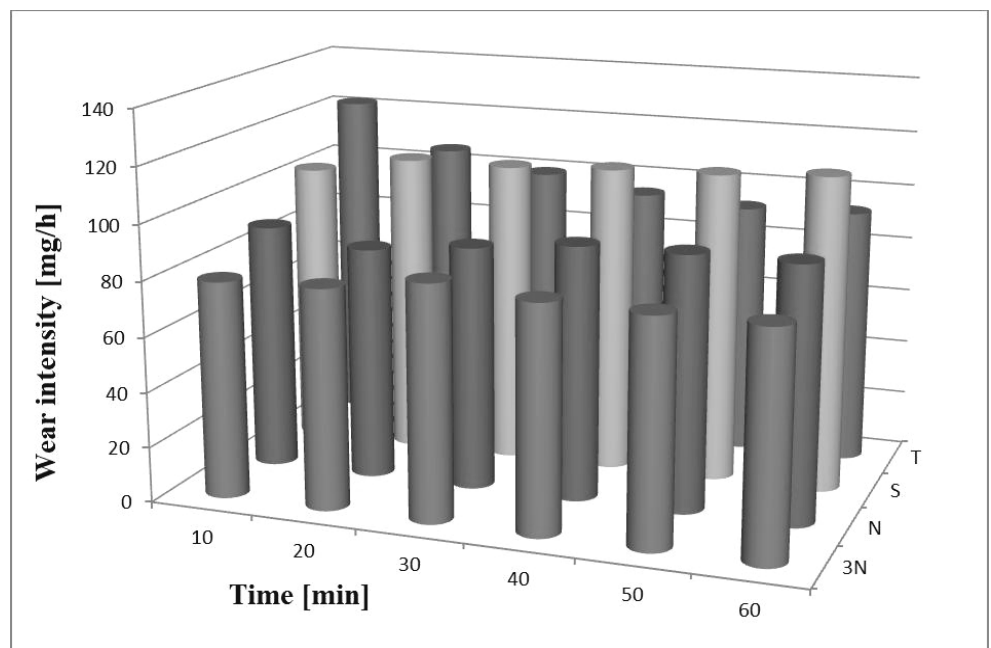

Fig. 5. Wear intensity for samples after: $T$ - finish turning, $S$ - grinding, $N$ - burnishing, $3 N-$ after 3 passes of burnishing tool

The research related to tribological wear aimed at defining the highest resistance to surface friction wear of marine shaft pins that underwent burnishing. These examinations had a comparative character. During the service of angular momentum pumps, properly shaped shaft pin surface can cooperate with the gland provided with a soft seal (flexible one) or with a slide gland. The application of burnishing process to 304L stainless steel enabled the achievement of such a geometric structure of the surface, which was characterized by a considerable decrease of roughness value as well as the surface material ratio. The mean values results of roughness parameters and the parameters of material ratio curve were presented in Tab. 5 and 6 . The surface burnishing process had a positive effect on tribological wear resistance by decreasing the protruding surface roughness summits.

Tab. 5. The mean values of surface roughness parameters for finish treatment

\begin{tabular}{|c|c|c|c|c|}
\hline Parameters & $\mathrm{R}_{\mathrm{a}}[\mu \mathrm{m}]$ & $\mathrm{R}_{\mathrm{q}}[\mu \mathrm{m}]$ & $\mathrm{R}_{\mathrm{t}}[\mu \mathrm{m}]$ & $\mathrm{R}_{\mathrm{z}}[\mu \mathrm{m}]$ \\
\hline Grinding & 0.28 & 0.36 & 2.66 & 2.07 \\
\hline Finish turning & 0.35 & 0.42 & 2.47 & 2.03 \\
\hline Burnishing - 1 tool passes & 0.07 & 0.09 & 0.85 & 0.59 \\
\hline Burnishing - 3 tool passes & 0.06 & 0.09 & 0.95 & 0.53 \\
\hline
\end{tabular}

Tab. 6. The mean values of material ratio parameters for finish treatment

\begin{tabular}{|c|c|c|c|c|c|c|}
\hline Parameters & $\mathrm{M}_{\mathrm{r} 1}[\%]$ & $\mathrm{M}_{\mathrm{r} 2}[\%]$ & $100 \%-\mathrm{M}_{\mathrm{r} 2}$ & $\mathrm{R}_{\mathrm{pk}}[\mu \mathrm{m}]$ & $\mathrm{R}_{\mathrm{vk}}[\mu \mathrm{m}]$ & $\mathrm{R}_{\mathrm{k}}[\mu \mathrm{m}]$ \\
\hline Grinding & 9.03 & 86.63 & 13.37 & 0.34 & 0.46 & 0.86 \\
\hline Finish turning & 6.47 & 87.73 & 12.27 & 0.25 & 0.49 & 1.17 \\
\hline Burnishing - 1 tool passes & 7.6 & 90.1 & 9.9 & 0.09 & 0.14 & 0.24 \\
\hline Burnishing - 3 tool passes & 8.2 & 87.6 & 12.4 & 0.08 & 0.13 & 0.21 \\
\hline
\end{tabular}

The influence of load on friction factor change at constant rotational speed was shown in Fig. 6 a. The influence of rotational speed on friction factor change at constant load was shown in Fig. 6b. 

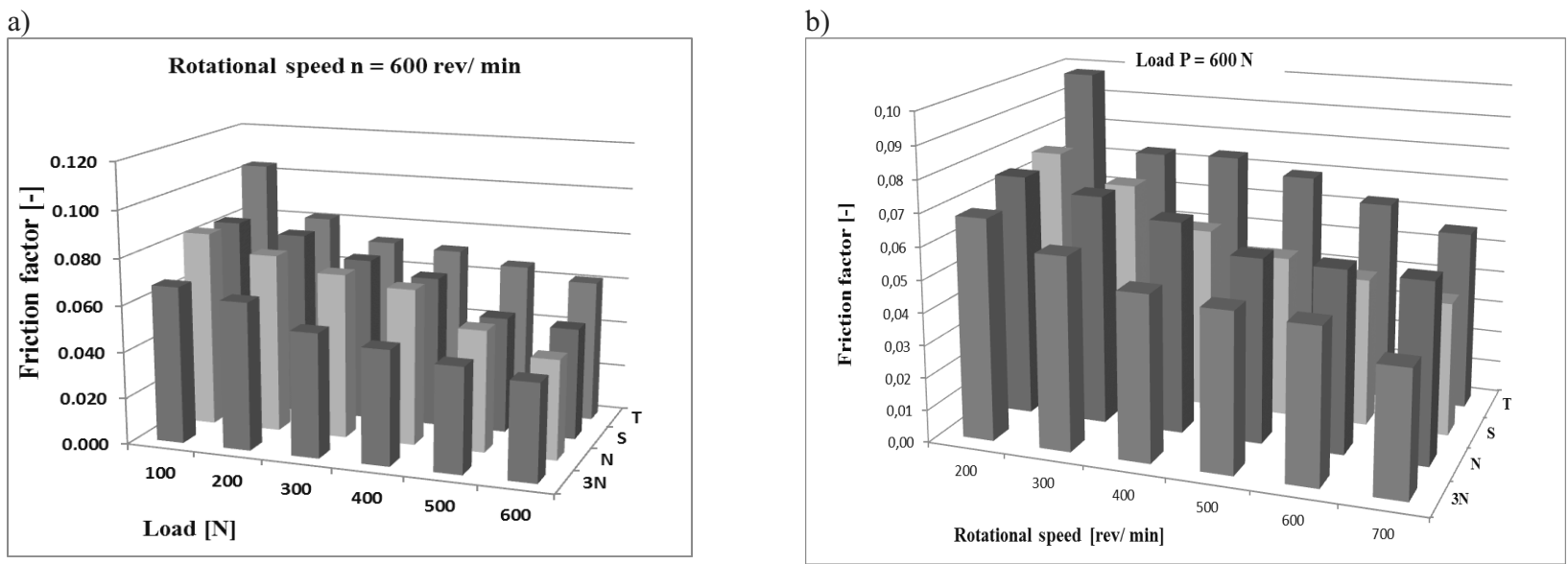

Fig. 6a. The diagram of load influence on friction factor at constant rotational speed, b) The diagram of rotational speed influence on friction factor at constant load: T-finish turning, $S$ - grinding, $N$ - burnishing, $3 N-$ after 3 passes of burnishing tool

The research into tribological phenomena performed at changeable load and at constant rotational speed showed that three passes of burnishing tool allowed obtaining the surface characterized by the lowest friction factor for full load range. At comparable level, it is possible to observe $\mu_{\mathrm{t}}$ values for samples after grinding as well as after burnishing. It signifies the achievement of a surface with similar surface layer properties for the above pins. The worst $\mu_{\mathrm{t}}$ result for the analysed tribological couples was found for the sample surface after turning. For all types of treatment processes that were carried out the load increase is followed by $\mu_{\mathrm{t}}$ value decrease. Due to the type of research of a given tribological couple, the issues related to the examination of standard load influence on the value of mixed friction force were analysed. Literature showed that according to Stribeck diagram [6] the factor for that type of friction in the function of pin rotational speed for different specific loads, at a given speed of $600 \mathrm{rev} / \mathrm{min}$ with the load increase causes friction factor decrease.

Friction factors that were obtained show that the value of $\mu_{\mathrm{t}}(0.1)$ at $200 \mathrm{rev} / \mathrm{min}$ signifies that during the first cycle the research a considerably high friction of sample and counter sample peaks took place. The loads applied could have caused a quick lapping of the cooperating surfaces. The other analysed samples were characterized by similar $\mu_{\mathrm{t}}$ values at the rotational speed of 200 $\mathrm{rev} / \mathrm{min}$. The $\mu_{\mathrm{t}}$ factors took similar values for all the samples at the rotational speed of 300 $\mathrm{rev} / \mathrm{min}$. When increasing the rotational speed values the sample after grinding has a minimally lower $\mu_{\mathrm{t}}$ values in comparison to the samples after lathing and burnishing. The tribologic pair that underwent three passes of a burnishing tool was characterized by the best properties. The research results obtained show that the increase of rotational speed is accompanied by the decrease of friction factor value for each analysed sample. The highest $\mu \mathrm{t}$ values were noted for the sample after finish turning which denotes the worst cooperation of a matched pair.

A significant decrease of roughness parameter values and a slight increase of hardness affected the improvement of operating conditions. Planishing the surface roughness caused the increase of resistance to corrosion because this surface has a smaller corrodible surface. On the other hand, a small hardening in the surface layer does not cause the formation of galvanic micro cells, which can speed up corrosion, in plastically deformed formation crystals.

\section{Conclusions}

The application of burnishing process increases the resistance to wear intensity of marine pump shafts working in seawater environment, when compared to traditional finish treatment methods. The shafts that were burnished three times showed the lowest mass decrement among the pairs tested for friction. The highest mass decrement was noted for ground shaft pins. 
The application of burnishing process improves the properties of tribological wear for marine pump shaft pins working in seawater environment in comparison with traditional finish treatment machining. The research showed that the best surface layer properties were achieved in the burnishing process after three passes of burnishing tool. Compared to traditional finish treatment methods the burnishing process performed in this way causes the decrease of friction factor in the study of load influence at constant speed. Planishing the surface by reducing the protruding surface roughness peaks improved the resistance to tribologic wear. The analysis of the influence of sample rotational speed at its constant load showed that the lowest friction factor in the whole range of loads belonged to shaft pins that underwent burnishing treatment comprising three passes of burnishing tool

\section{References}

[1] Charchalis, A., Starosta, R., Labuda, W., Estimation of the influence of burnishing tool passes number on ships pumps shafts surface layers strengthening and roughness changes, Journal of KONES Powertrain and Transport, Vol. 16, No. 4, pp. 43-50, Zakopane 2009.

[2] Charchalis, A., Starosta, R., Labuda, W., Multi-criteria optimization of steel burnishing parameters applied to marine pumps shaft pins, Journal of KONES Powertrain and Transport, Vol. 17, No. 3, pp. 55-62, Jurata 2010.

[3] Charchalis, A., Starosta, R., Labuda, W., The influence of burnishing parameters on the roughness, plastic strain and shape deviations of marine pumps crankshaft pins in fresh water installations, Journal of KONBiN, No 1-2 (9,10), pp. 57-66, Warszawa 2009.

[4] Dyl, T., Skoblik, R., Starosta, R., The Effect of the Ceramic Dispersion on the Nickel Matrix Composite Coating Properties after Plastic Working, Solid State Phenomena, Vol. 147-149, pp. 813-818, Switzerland 2009.

[5] Dyl, T., Starosta, R., Skoblik, R., The effect of the unit pressure on the NiAl and Ni3Al intermetallic coatings selection parameters after plastic working, Solid State Phenomena, Vol. 165, p. 19-24, Switzerland 2010.

[6] Jacobson, B., The Stribeck memorial lecture, Tribology International, No. 36, pp. 781-789, 2003.

[7] Labuda, W., Starosta, R., Estimation of the influence of burnishing parameters on X5CrNi1810 steel, Solid State Phenomena, Trans Tech Publication, Vol. 165, pp 300-305, Switzerland 2010.

[8] Labuda, W., Starosta, R., Dyl, T., Estimation of the influence of burnishing parameters on steel X5CrNi1810 surface layers strengthening and roughness changes, Journal of KONES Powertrain and Transport, Vol. 15, No. 3, pp. 259-267, Warszawa 2008.

[9] Starosta, R., The influence of plastic strain on the corrosive properties of plasma sprayed intermetallic NiAl and Ni3Al coatings, Solid State Phenomena, Vol. 165, pp. 165-177, Switzerland 2010.

[10] Przybylski, W., Wspótczesne problemy w technologii obróbki przez nagniatanie, Wydawnictwa Politechniki Gdańskiej, Gdansk 2005.

[11] Przybylski, W., Współczesne problemy $w$ technologii obróbki przez nagniatanie, Tom 2, Wydawnictwa Politechniki Gdanskiej, Gdansk 2008. 